\title{
乾式系における超微粒子シリカとアルキルアルコキシシランとの 反応性に及ぼすアルキル鎖長の影響
}

\author{
室田正道*・坪川紀夫**
}

\begin{abstract}
要 旨
乾式法による超微粒子シリカとアルキルアルコキシシランとの反応性に及ぼすアルキルアルコキシシランの添加量やアルキル 鎖長の影響について検討した。その結果, シリカのシラノール基に対するアルキルアルコキシシラン添加量の物質量比を増大す ると処理シリカのカーボン量が増加し，シラノール基量が減少することがわかった。また，アルキルアルコキシシランの添加量 が増加するにしたがって，アルキルアルコキシシラン処理シリカの疎水化度が増加することが明らかとなった。さらに，アルキ ルアルコキシシランのアルキル鎖長が長くなるほど表面炭素量や疎水化度が大きくなることがわかった。しかしながら, 摩擦帯 電性はアルキル鎖長が変化してもほとんど変わらなかった。また, 反応率はアルキル鎖長が長くなるほど, 小さくなることが明 らかとなった。さらに，シリカ表面のシラノール基に対するアルキルアルコキシシランの最適量は $2 / 3$ (物質量比) のときであ ることがわかった。
\end{abstract}

\section{1. 緒言}

シリカ表面をシランカップリング剤で化学修飾することによ り，粒子表面に様々な機能を付与することができる1)。たとえ ば，シリカを適当なカップリング剤で処理することにより， シ リカ表面への疎水性付与 ${ }^{2 \sim 5}$, 分散性制御 ${ }^{6)}$, 帯電特性制御 7 , 複合液体系におけるレオロジー制御8,9)などが可能になる。した がって，機能性材料を設計する上で，シリカやシランカップリ ング剤の選定は重要となる。

ところで, 一般にシリカの表面改質は湿式法で行われてい

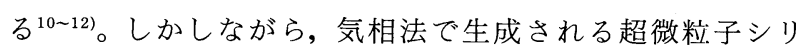
カ ${ }^{13 \sim 15)}$ の場合, それ自身が比較的緩い凝集状態を保っており, 表面改質を湿式法で行うと, さらに凝集を進行させてしまうと いう問題点がある。これに対して, 乾式法はシリカ粒子の凝集 を起こすことなく，大量の処理が可能であり，環境への影響を 考え合わせると，工業的にも優れた方法である。

また，シランカップリング剤の添加量を，シリカ表面に単分 子層を形成するために必要な量から求める方法 ${ }^{16)}$ が提案されて いるが，比表面積が大きな超微粒子シリカにこの方法を適用す ると, 多量の改質剤が必要となり不適切である。さらに, 無機 微粒子, とくに超微粒子シリカとアルキルアルコキシシランの

\footnotetext{
平成 12.10 .18 受理

* 新潟大学大学院 自然科学研究科

新潟県新潟市五十嵐二の町 8050（广 950-2181）

** 新潟大学工学部 機能材料工学科

新潟県新潟市五十嵐二の町 8050（广 950-2181）
}

反応性に及ほすすアルルアルコキシ基の添加量やアルキル鎖長 の影響についての詳細な検討を行った報告はほとんどない。

そこで, 本研究では乾式系における超微粒子シリカとアルキ ルアルコキシシランとの反応性に及ぼすアルキル鎖長の影響, およびアルキルアルコキシシラン添加量とシリカ表面へ導入さ れたカーボン量, シラノール基量, 疎水化度, さらには摩擦帯 電性との関係についてしらべた。

これらの結果から, シリカ表面へのアルキルアルコキシシラ ンの固定化反応条件の最適化を行うとともに, 反応性に及ぼす アルキル基の側鎖基の影響や，アルコキシ基の影響についても 考察した。

\section{2. 実 験}

\section{1 シリカと試薬}

本実験に用いた超微粒子シリカは，日本アエロジルより提供 を受けた AEROSIL 200 （比表面積, $200 \mathrm{~m}^{2} / \mathrm{g}$; 平均粒径, 12 $\mathrm{nm}$; シラノール基量, 2.5 個 $/ \mathrm{nm}^{2}$ ) である。アルキルアルコ キシシランは, 信越化学株式会社製のモノメチルトリメトキシ シラン $\left(\mathrm{C}_{1}\right.$-silane $)$, ジメチルジメトキシラン, トリメチルメ トキシシラン, $\mathrm{n}$-プロピルトリメトキシシラン $\left(\mathrm{C}_{3 \mathrm{n}^{-}}\right.$ silane), $\mathrm{n}$-ブチルトリメトキシシラン $\left(\mathrm{C}_{4 \mathrm{n}}\right.$-silane $)$, iso-ブ チルトリメトキシシラン $\left(\mathrm{C}_{4 \mathrm{i}} \mathrm{-}\right.$ - $\left.\mathrm{silane}\right), n^{-ヘ キ シ ル メ チ ル ト ~}$ リメトキシシラン $\left(\mathrm{C}_{6}\right.$-silane $), \mathrm{n}$-オクチルトリメトキシシラ ン $\left(\mathrm{C}_{8}-\right.$ silane $), \mathrm{n}$-デシルトリメトキシシラン $\left(\mathrm{C}_{10}-\right.$ silane $)$, $\mathrm{n}$-ドデシルトリメトキシシラン $\left(\mathrm{C}_{12}-\right.$ silane $), \mathrm{n}$-ヘキサデシ ルトリメトキシシラン $\left(\mathrm{C}_{16}\right.$ - silane $)$, およびn-オクタデシル 


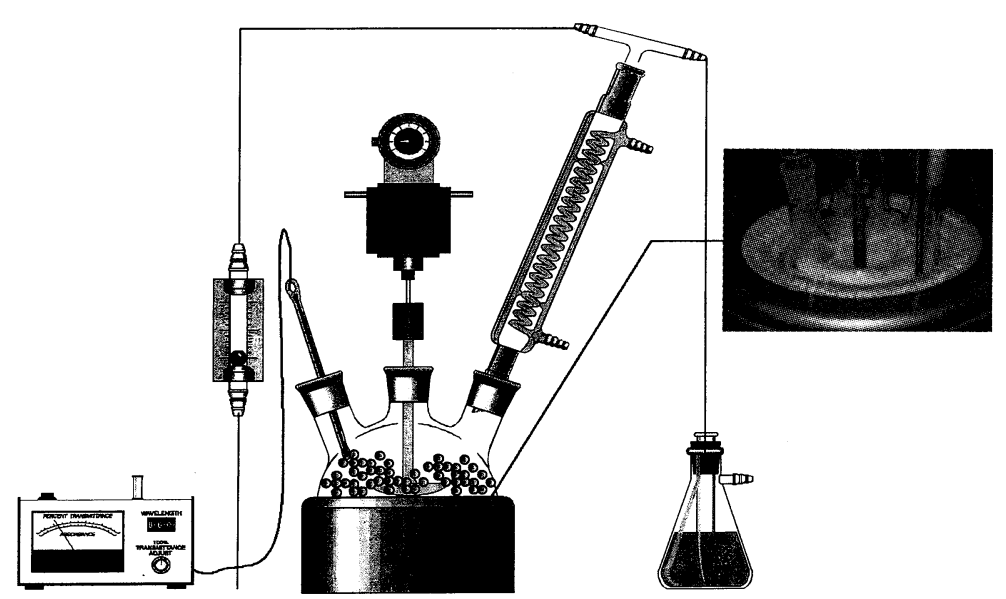

Fig. 1 Reaction apparatus for the synthesis of surface modified silica in a dry system.

トリメトキシシラン $\left(\mathrm{C}_{18}-\right.$ silane $)$ を用いた。これらのアルキ ルアルコキシシランは精製することなくそのまま使用した。

\section{2 シリカのアルキルアルコキシシラン処理}

アルキルアルコキシシラン処理によるシリカ表面へのアルキ ル基の導入は，シリカを流動化させながら水/アルキルアルコ キシシラン系で均一に処理する乾式法により行った。図-1に 本実験で用いた実験装置を示す。すなわち, かくはん器, 温度 計，および冷却機を取りつけた $2 \mathrm{~L}$ の 4 ロフラスコにシリカ $30 \mathrm{~g}$ を加え, 窒素で反応容器を置換した。次いでシリカをかく はんしながら，アルコキシ基の加水分解に必要な量の水を噴霧 し，その後，アルキルアルコキシシランを噴霧して， $250^{\circ} \mathrm{C} て ゙$ 180 分間反応させた。反応後, 冷却機を取り除き, $250^{\circ} \mathrm{C} て ゙$ 加 熱しながら窒素ガスとともにアルコールを除去した。

\section{3 表面特性評価}

アルキルアルコキシシランで処理したシリカの IR スペクト ルは FT/IR 分析装置（FT/IR-300 型日本分光製）を用い拡散 反射法で測定した。

シリカ表面に導入されたカーボン量は，メタノール水溶液で ソックスレー抽出を 3 時間行ってから炭素元素分析装置 (EMIA-1/10 型 HORIBA 社製) により求めた。

シリカ表面のシラノール基量は, $120^{\circ} \mathrm{Cで} 2$ 時間真空乾燥後 室温まで泠却し，リチウムアルミニウムハイドライド法苚によ り測定した。すなわち，シラノールとリチウムアルミニウムハ イドライド溶液を反応させ, 発生する水素量を測定することに より行った。

疎水化度 (MW; Methanol Wettability) は, $200 \mathrm{ml}$ ビー カーに $50 \mathrm{ml}$ の純水と $0.2 \mathrm{~g}$ の処理シリカとを入れかくはんし ながらメタノールを滴下し, 水面に浮かんでいたシリカが沈降 するまでのメ夕ノールの滴定量を測定し, 式一 1 から求めた。

$$
\begin{aligned}
& \mathrm{MW}(\%)=\mathrm{A} /(50+\mathrm{A}) \times 100 \\
& \mathrm{~A}=\text { メタノール滴下量 }(\mathrm{ml})
\end{aligned}
$$

単位重量あたりの摩擦帯電量 $(\mathrm{Q} / \mathrm{M})$ は，つぎの方法により 求めた。すなわち, $50 \mathrm{~g}$ の鉄粉キャリアに $0.1 \mathrm{~g}$ の処理シリカ をターブラミキサー（T 2 C 型 WAB 製）を用い $90 \mathrm{rpm} に て 5$

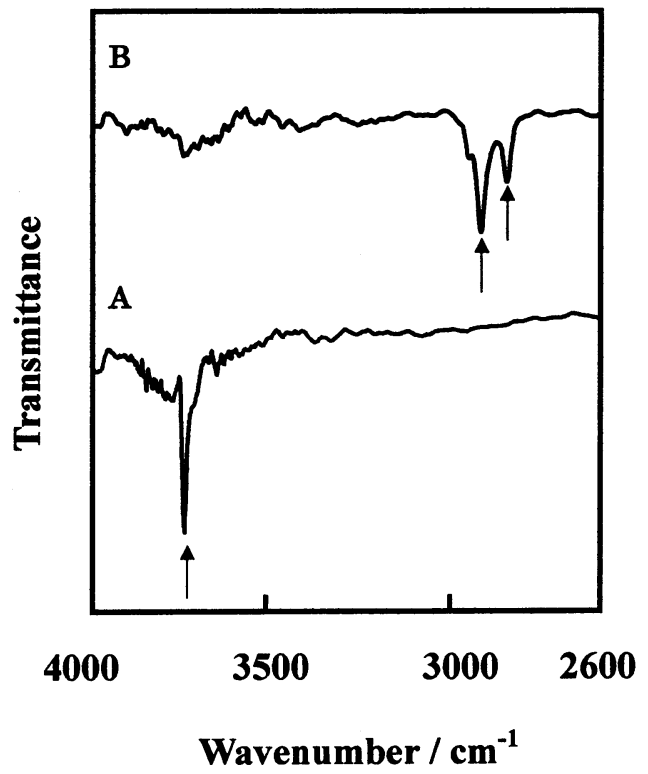

Fig. 2 IR spectra of (A) untreated silica and (B) $\mathrm{C}_{10}$-silane-treated silica.

分間分散させた。その後, 試料を $0.1 \mathrm{~g}$ 採取しブローオフ帯電 量測定装置（TB-200 型東芝ケミカル製）を用い，1分間窒素 ガスでブローオフを行い帯電量を測定し, 式一2 から摩擦帯電 量を算出した。

$$
\begin{gathered}
\mathrm{Q} / \mathrm{M}\left(\mu \mathrm{C} \mathrm{g}^{-1}\right)=-\mathrm{B} / 2.0 \times 10^{-4} \\
\mathrm{~B}=\text { 摩擦帯電量 }(\mu \mathrm{C})
\end{gathered}
$$

\section{3. 結果と考察}

\section{1 アルキルアルコキシシラン添加量の影響}

超微粒子シリカおよび $\mathrm{C}_{10}-$ Silane で表面改質した超微粒子 シリカのIR スペクトルの一例を図-2に示す。末処理の超微粒 子シリカ（A）には，孤立シラノール基の大きなピーク（3745 $\left.-3760 \mathrm{~cm}^{-1}\right)$ が観察されるが，表面処理超微粒子シリカ（B） では孤立シラノール基のピークが非常に小さくなっており，代 


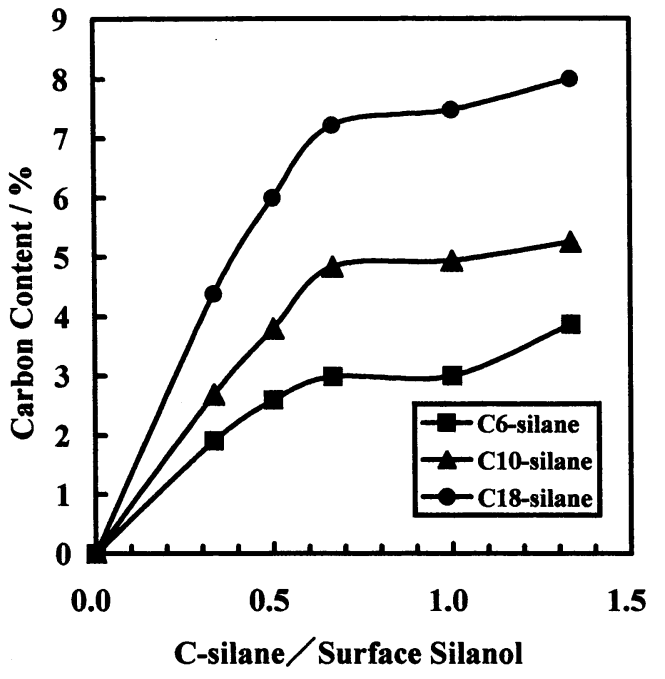

Fig. 3 Relationship between carbon content of alkylalkoxysilane-treated silica and charged ratio of alkylalkoxysilane to silanol group of silica (C-silane/Surface Silanol).

わりにメチレン基の $\mathrm{C}-\mathrm{H}$ 伸縮振動のピーク（2860，2930 $\left.\mathrm{cm}^{-1}\right)$ が観察された。このことから， $\mathrm{C}_{10}-$ Silane で処理した 超微粒子シリカ表面にはアルキル基が存在することが確かめら れた。

アルキルアルコキシシラン処理後のカーボン量とアルキルア ルコキシシランの添加量との関係を図-3に示す。横軸はアル キルアルコキシシランとシリカ表面のシラノール基との物質量 比 (C-Silane/Surface Silanol) を示す。アルキルアルコキシ シランとして, $\mathrm{C}_{6}$-Silane, $\mathrm{C}_{10}-$ Silane, および $\mathrm{C}_{18}-$ Silaneを 用いた例を示した。

いずれの系でも，アルキルアルコキシシランの増加にともな い, カーボン量は増加するが, 増加傾向は常に一定でなく, ア ルキルアルコキシシランとシリカシラノールの物質量比が $2 / 3$ （0.67）までは, 顕著にカーボン量は増加するが，2/3 以上で はカーボン量の増加傾向は小さいことがわかる。これらの結果 は, アルキルアルコキシシラン添加量がシリカ表面との反応性 に影響を及ぽすことを示唆しており，アルキルアルコキシシラ ンの最適な添加量は $2 / 3(0.67)$ であることがわかった。

図-4にアルキルアルコキシシラン処理後の全シラノール基 量とアルキルアルコキシシランの添加量との関係を示す。な お, 全シラノール基には, シリカ由来のシラノール基と, シリ カとアルキルアルコキシシランの反応によってシリカ表面に固 定化されたアルキルアルコキシシランの未反応アルコキシシリ ル基の加水分解によるシラノールが含まれる。また，未処理の シリカのシラノール基量は 2.5 個 $/ \mathrm{nm}^{2}$ である。

アルキルアルコキシシランの増加にともない，アルキルアル コキシシランとシリカのシラノール基の物質量比が $2 / 3$ 付近ま では, シラノール基量は小さくなる傾向があり， $2 / 3$ から $1 / 1$ まではアルキルアルコキシシラン増加によるシラノール基量の

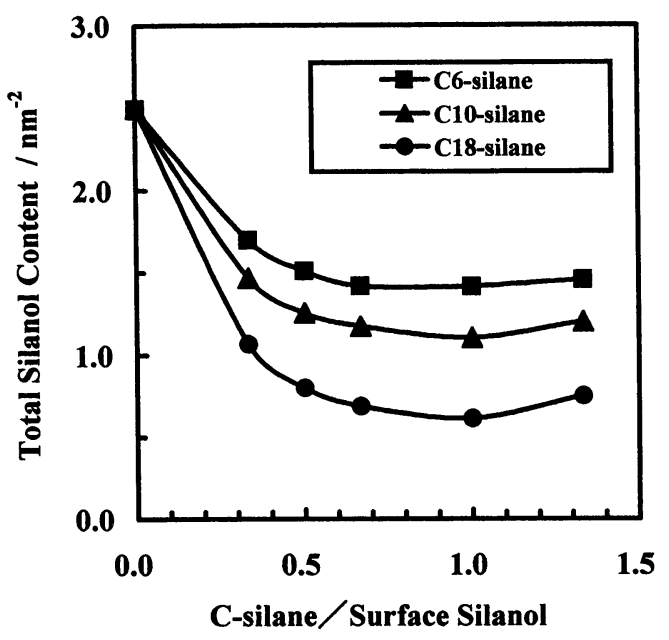

Fig. 4 Relationship between total silanol content of alkylalkoxysilane-treated silica and charged ratio of alkylalkoxysilane to silanol group of silica (C-silane/Surface Silanol).

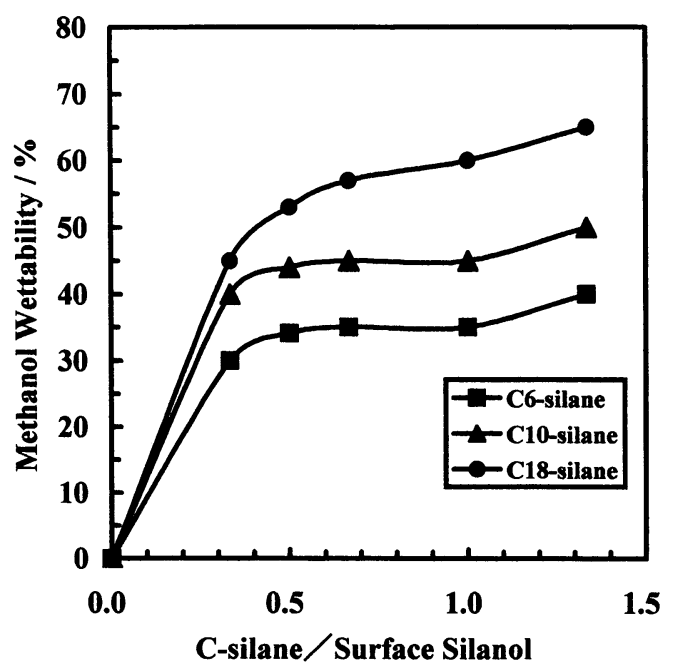

Fig. 5 Relationship between methanol wettability of alkylalkoxysilane-treated silica and charged ratio of alkylalkoxysilane to silanol group of silica (C-silane/Surface Silanol).

増加はほとんどなくなった。このことは，アルキルアルコキシ シランの添加量が多くなると表面シラノール基とアルキルアル コキシシランとの反応が促進されることを示している。一方, アルキルアルコキシシランの添加量が $1 / 1$ 以上になるとシラノ ール基量がかえって増える傾向があることがわかった。このよ うな現象は, アルキルアルコキシシランの未反応アルコキシシ ラン基の加水分解により生成したシラノール基によるものと考 えられる。したがって，これからもアルキルアルコキシシラン の最適な添加量は $2 / 3(0.67)$ であることがわかった。

また, $\mathrm{C}_{6}-$ Silane, $\mathrm{C}_{10}-$ Silane, $\mathrm{C}_{18}-$ Silane とアルキル基が 長くなるほど全シラノール基量が少なくなることがわかった。

図-5にアルキルアルコキシシラン処理後の疎水化度 (MW) とアルキルアルコキシシランの添加量との関係を示す。 


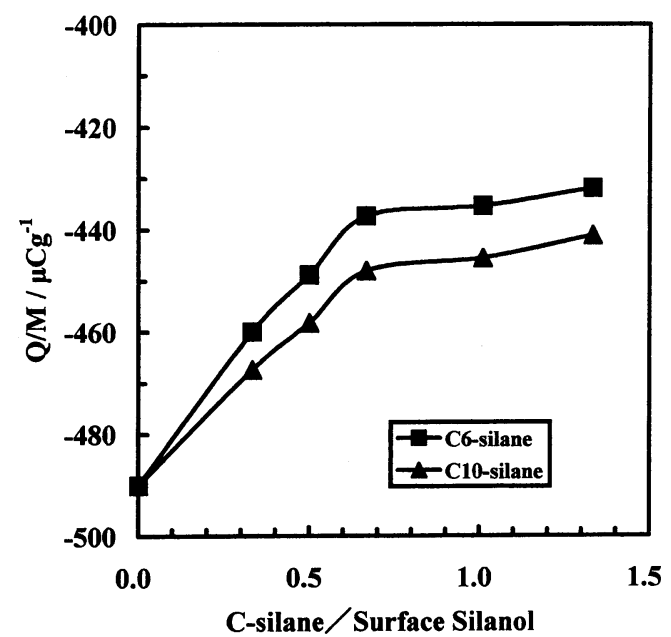

Fig. 6 Relationship between Q/M of alkylalkoxysilanetreated silica and charged ratio of alkylalkoxysilane to silanol group of silica (C-silane/Surface Silanol).

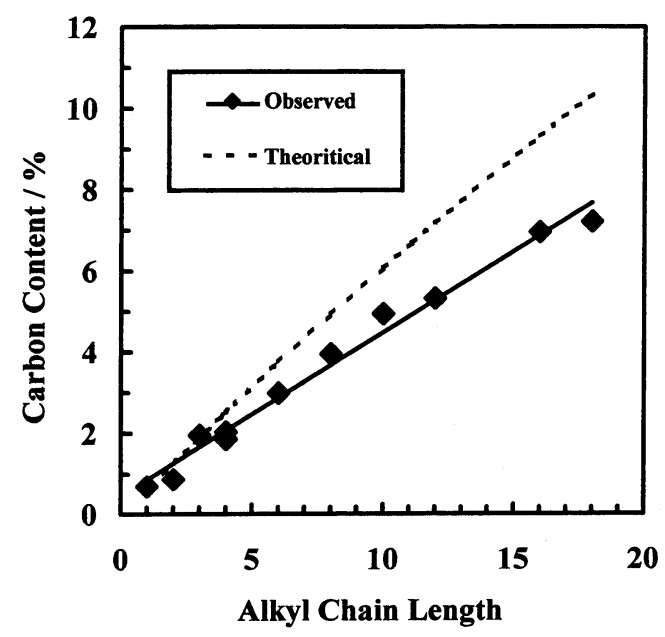

Fig. 7 Relationship between carbon content of alkylalkoxysilane-treated silica and alkyl chain length.

MW 值の大きい方が粒子表面が高疎水性であることを示す。 これから, MW はアルキルアルコキシシラン添加量とシリカ のシラノールの物質量比が $2 / 3$ まで疎水性は増加するが, それ 以上添加量を増やしても疎水性の変化はほとんど認められなく なった。これは先に示した図-3の結果からもわかるように物 質量比が $2 / 3$ 以上ではカーボン量の増加がないこと，すなわち アルキルアルコキシシランがこれ以上反応しなくなったことに 起因するものと考えられる。また，アルキル鎖長が長いほど， シリカ表面の疎水性が大きくなることもわかる。

図-6には，アルキルアルコキシシラン処理後の単位重量あ たりの摩擦帯電量 $(\mathrm{Q} / \mathrm{M})$ とアルキルアルコキシシラン添加 量との関係を示す。絶縁性の高いシリカは, 鉄やフェライトに 対する負の帯電性が強い特徵を持っている。摩擦帯電性は, 表 面の状態（疎水基，親水基の影響）に大きく影響する。ここで は，アルキルアルコキシシランの添加量, すなわちシリカ表面

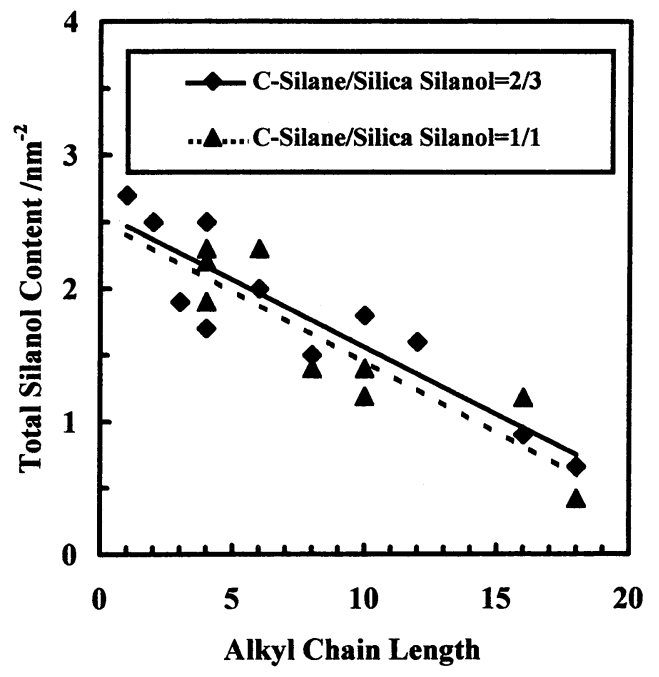

Fig. 8 Relationship between total silanol content of alkylalkoxysilane-treated silica and alkyl chain length.

のアルキル基量の増加により, 摩擦帯電性が弱くなることが確 認されたが，その効果はあまり大きくなかった。

これは，親水性のシラノール基は带電性を弱め，一方疎水性 のアルキル基は帯電性を負に強めることを考慮すると, 処理シ リカの摩擦帯電性に及ぼす効果はアルキル基よりもシラノール 基の方が大きいためと考えられる。

\section{2 アルキルアルコキシシランのアルキル鎖長の影響}

図-7には，アルキルアルコキシシラン処理後のシリカ表面 のC 量とそのアルキル鎖長との関係について示す。ここで点 線は, 添加量に対する理論カーボン量である。アルキル鎖長が $\mathrm{C} 4$ 以下の小さいときはほぼ理論どおりのカーボン量となる が, とくにC 12 以上の場合, カーボン量は理論值より相当小 さくなることがわかる。

図-8には, 全シラノール基量とアルキル鎖長との関係を示 す。実線がアルキルアルコキシシランとシリカシラノール基と の割合が $2 / 3$ で, 点線が $1 / 1$ の結果であるが, この系ではアル キルアルコキシシランの添加量の違いはほとんどないことがわ かる。また，アルキル鎖が長くなるほど全シラノール基量は小 さくなることがわかる。この結果は, アルキル鎖長が長くなる にしたがい，シリカ表面とのアルキル鎖による立体障害が大き くなり, シラノール基が十分リチウムアルミニウムハイドライ ドと反応できなかったことや，シリカ表面との反応で 1 分子の アルキルアルコキシシランが $2 \sim 3$ 個の表面シラノール基を消 費するためと考えられる。

さらに図-9には, 疎水化度とアルキル鎖長との関係につい てしらべた結果を示す。アルキル鎖長が長いほど疎水化度は高 くなるというリニアな関係が得られた。

つぎに図-10には単位重量あたりの摩擦帯電量 $(\mathrm{Q} / \mathrm{M})$ とア ルキル鎖長との関係を示す。アルキル鎖長が短い場合も長い場 合も，摩擦帯電性に大きな影響がないことがわかった。これら の結果から，疎水基と親水基のバランスが保たれたこのような 


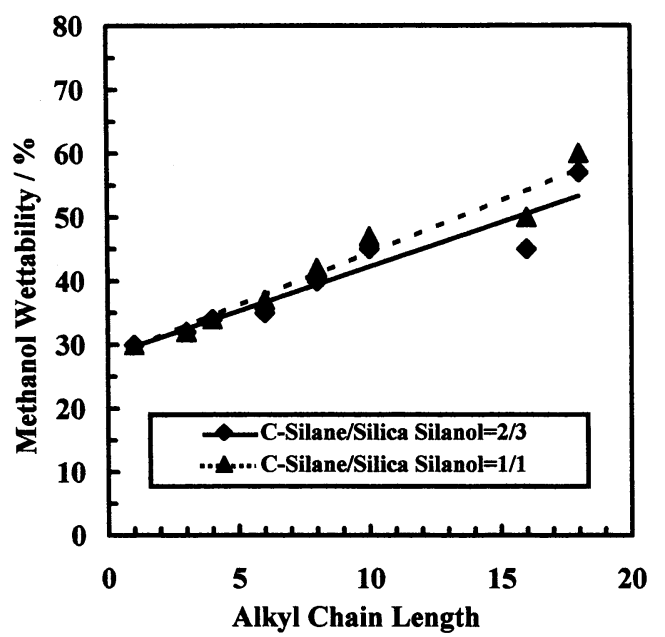

Fig. 9 Relationship between methanol wettability and alkyl chain length of alkylalkoxysilane.

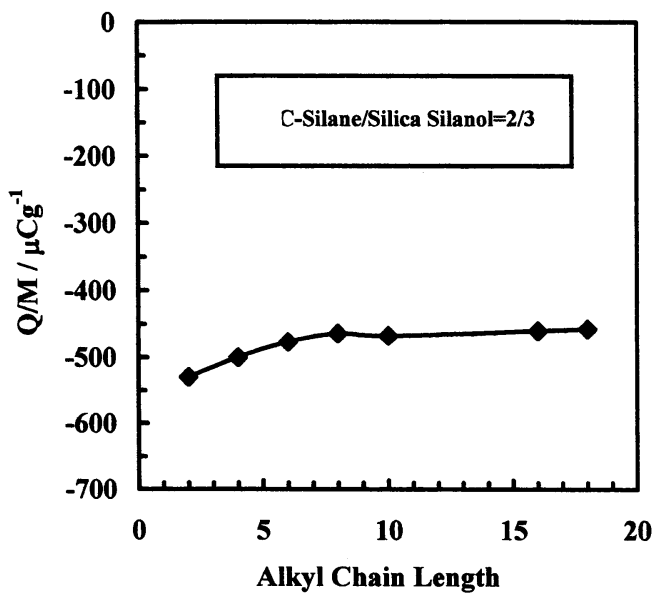

Fig. 10 Relationship between $Q / M$ and alkyl chain length of alkylalkoxysilane.

系では，アルキル鎖長はほとんど摩擦帯電性に影響を及ぼさな いことがわかった。

\section{3 反応率に及ぼす影響}

図-11に,アルキルアルコキシシランの反応率とアルキル鎖 長の関係についてしらべた。反応率は, 式一 3 から求めた。な お，アルキルアルコキシシランとの反応はシリカに水を吸着さ せた後行っているので, アルキル基導入後のカーボン量に及ぼ すメトキシ基由来のカーボンの影響は無視した。

$$
\text { 反応率 }(\%)=(\mathrm{A} / \mathrm{B}) \times 100
$$

$$
\begin{aligned}
\mathrm{A}= & \text { アルキル基導入後のカーボン量 } \\
\mathrm{B}= & \text { 仕込みアルキルアルコキシシランのアルキル基のカー } \\
& \text { ボン量 }
\end{aligned}
$$

図-11 からアルキル鎖長が長くなるほどアルキルアルコキシ シランの反応率は, 減少する傾向が見られた。また, その減少 傾向はオクタデシル基にいたるまで 3 つの段階に分かれること がわかる。すなわち, 鎖長が短いときは鎖長の増加とともに反 応率は低下するが，中間鎖長域では反応率に及ぼすアルキル鎖

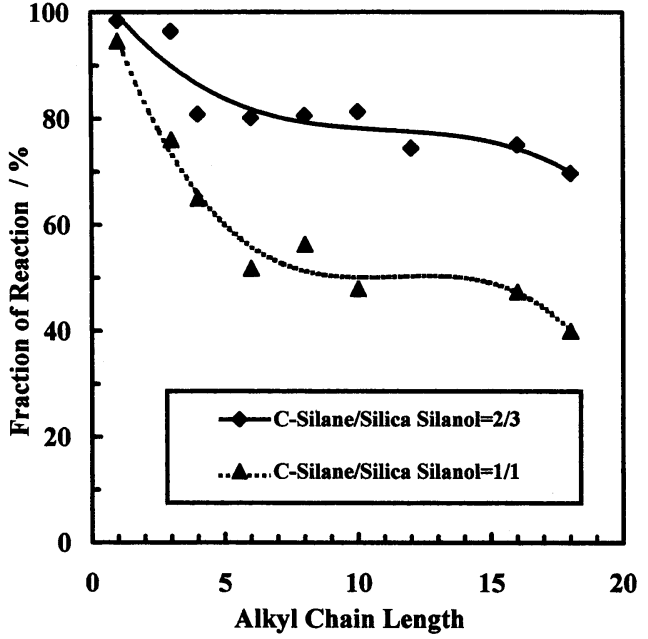

Fig. 11 Relationship between fraction of reaction and alkyl chain length of alkylalkoxysilane.

Table 1 Fraction of the reaction between surface silanol groups and alkoxysilanes with different alkyl groups

\begin{tabular}{lc}
\hline \multicolumn{1}{c}{ Reagent } & $\begin{array}{c}\text { Fraction of } \\
\text { Reaction }(\%)\end{array}$ \\
\hline $\mathrm{C}_{3} \mathrm{H}_{7} \mathrm{Si}\left(\mathrm{OCH}_{3}\right)_{3}$ & 100 \\
$\mathrm{C}_{4} \mathrm{H}_{9} \mathrm{Si}\left(\mathrm{OCH}_{3}\right)_{3}$ & 81 \\
$\left(\mathrm{CH}_{3}\right)_{2} \mathrm{C}_{2} \mathrm{H}_{4} \mathrm{Si}\left(\mathrm{OCH}_{3}\right)_{3}$ & 74 \\
\hline
\end{tabular}

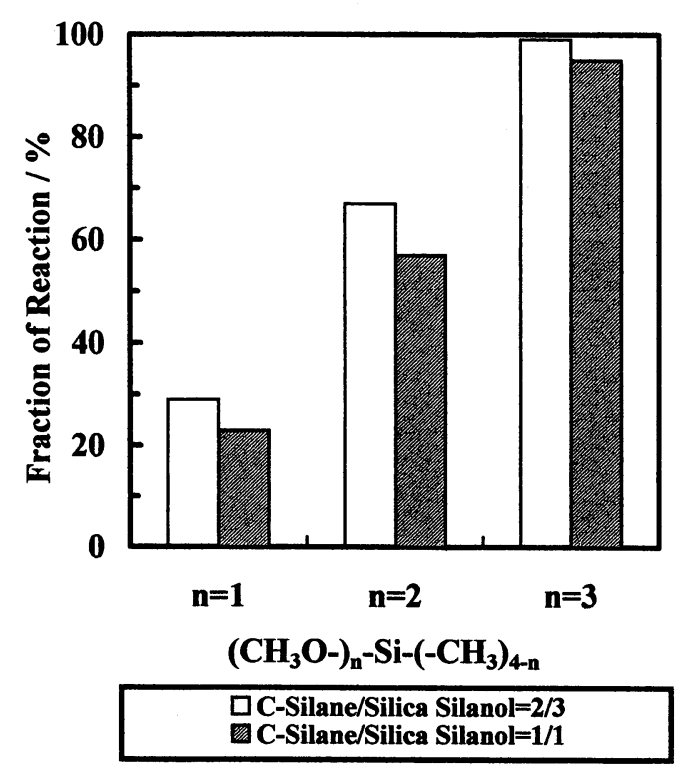

Fig. 12 Fraction of reaction on the effect of alkoxy group of alkylalkoxysilane.

長の影響があまり認められなかった。さらに鎖長が長くなる

と, 反応率が鎖長の増加とともに低下した。

また, アルキルアルコキシシランとシリカ表面のシラノール 基の比が $1 / 1$ のときより，2/3 の方が高い反応率を示すことか ら $2 / 3$ 程度を用いた方がより効果的であることがわかる。

表-1 に，反応率に及ぼすアルキルアルコキシシランのアル 
(a) C-Silane $/$ Silica Silanol $=1 / 2$
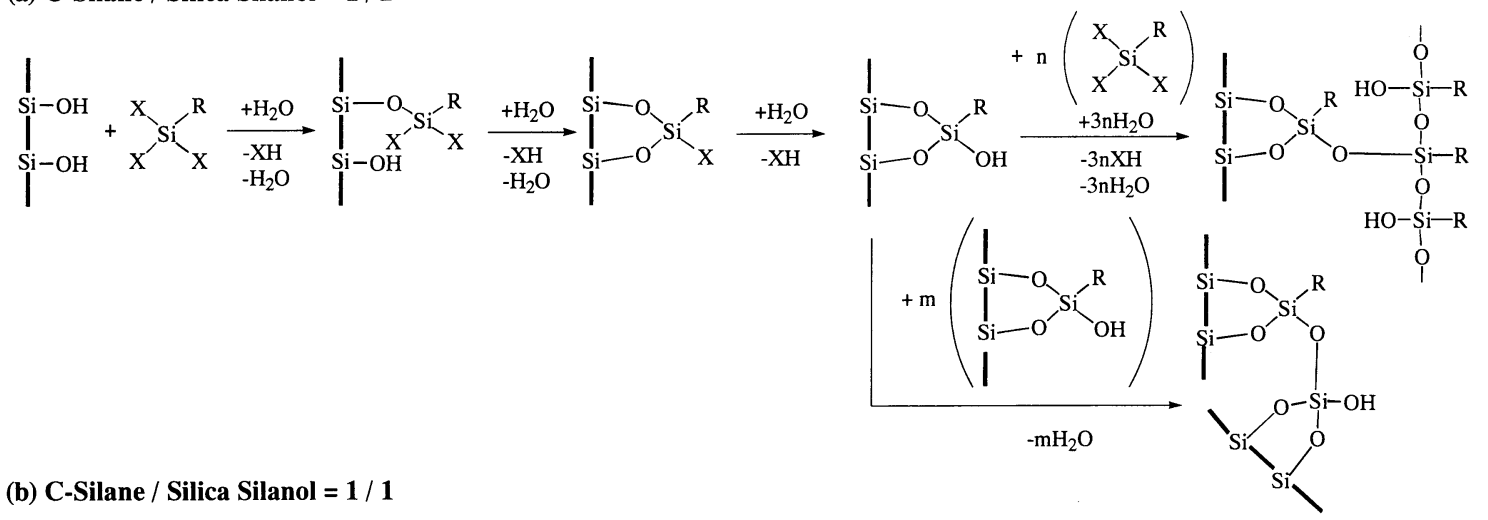

(b) C-Silane $/$ Silica Silanol $=1 / 1$
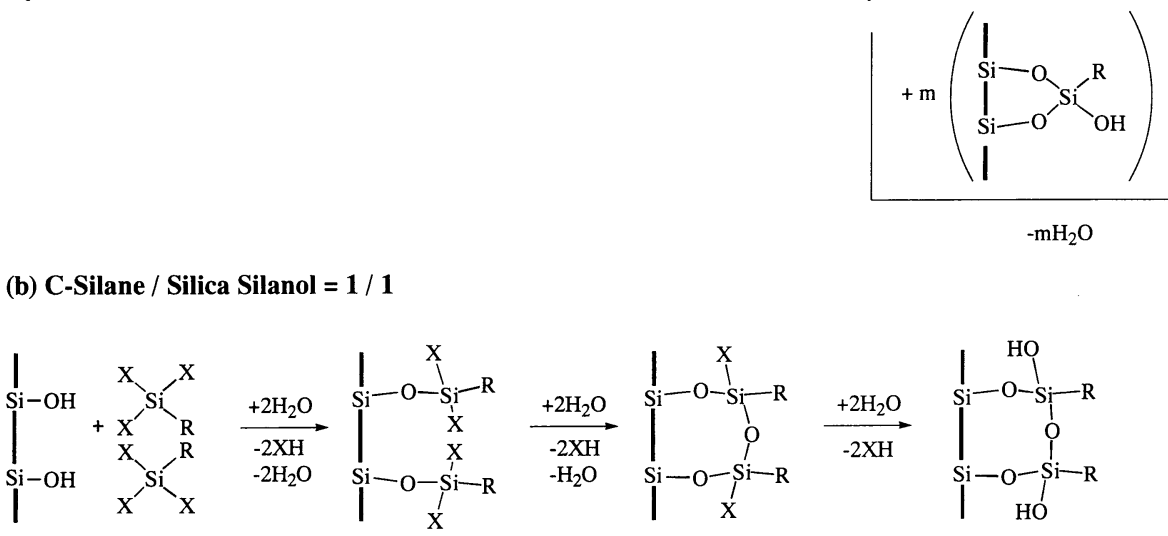

$$
\begin{aligned}
& \mathrm{X}=\mathrm{CH}_{3} \mathrm{O} \\
& \mathrm{R}=\text { alkyl group }
\end{aligned}
$$

Fig. 13 Reaction mechanism of silanol groups on silica surface with alkylalkoxysilane.

キル基の側鎖の影響についてしらべた結果を示す。 $\mathrm{n}$-プロピル トリメトキシシランの反応率は $100 \%$ であるのに対して, n-ブ チルトリメトキキシランの反応率は $81 \%$ ，iso-ブチルトリメト キシシランは $74 \%$ であった。この結果から，アルキル鎖長を プロピル基からブチル基にかえることで反応率は急激に下が り，さらにアルキル基末端が分岐することでさらに反応性が下 がることが確認された。

図-12に，モノメチルトリメトキシシラン，ジメチルジメト キシシラン，およびトリメチルモノメトキシシランを用いて， シリカ表面のシラノール基との反応性に及ほすすアルコキシ基の 数の影響についてしらべた結果を示す。トリメトキシ基，ジメ トキシ基，モノメトキシ基の順にメトキシ基の数が減少するに 従い, 反応率は，100\%，65\%，20\% と大きく減少した。これ らの結果からアルキルアルコキシシランのアルコキシ基の数が 多いほど，シリカ表面のシラノール基との反応性が大きくなる ことが確認できた。

\section{4 シリカ表面のシラノール基とアルキルアルコキシシラン の反応様式}

図-13 に, シリカ表面のシラノール基と 3 官能性のアルキル アルコキシシランの反応式を示す。図 -3 と図 -4 に示したよう に, シリカ表面のシラノール基に対するアルキルアルコキシシ ランの最適量は $2 / 3$ (物質量比) であるので, シリカ表面のシ ラノール基とアルキルトリアルコキシシラン（3 官能性）との 反応においては，つぎの 2 つの反応（図-12(a)と(b)) が進行 するものと思われる。

すなわち, 1 つは, シリカ表面の 2 つのシラノールと 1 分子 のアルキルアルコキシシランとの反応 $(2: 1$ の反応形態 $(\mathrm{a}))$ であり, もう 1 つはシリカ表面の 1 つのシラノールと 1 分子の アルキルアルコキシシランとの反応（1：1の反応形態 $(\mathrm{b}))$ で ある。
一方, $2 / 3$ (物質量比) 以上の場合, すなわちアルキルアル コキシシランが過剩の場合, 反応形態は, 図-12(b)のような形 態が多くなるものと考えられ, 逆にアルキルアルコキシシラン が少ない場合は図-12(a)のような形態が多くなるものと推察さ れる。

\section{4. 結 論}

1. シリカ表面の処理に用いるアルキルアルコキシシランの 量が処理シリカのカーボン量, シラノール基量, 疎水性, およ び摩擦帯電性に及ほす影響はアルキルアルコキシシランの添加 量とシリカのシラノールの物質量比が $2 / 3$ 以下, $2 / 3 \sim 1 / 1,1 /$ 1 以上の 3 つの領域により傾向が異なることを見いだした。

2.アルキルアルコキシシランのアルキル鎖長が処理シリカ のシラノール基量や疎水化度，带電性に影響を及ぼすことが明 らかとなった。

3.アルキルアルコキシシランとシリカ表面のシラノール基 との反応性に及ぼすアルキル鎖長の影響をしらべた結果, アル キル鎖長が長くなると立体障害の影響が大きくなり，反応率が 低下することが明らかとなった。

4. シリカ表面のシラノール基とアルキルトリアルコキシシ ランとの反応形式について考察した。

\section{文献}

1）篠田純雄, 斎藤泰和：表面，21，722（1983）.

2）城野博州：色材，61，618（1988）.

3）中村雅彦，辻井清司：材料，41，202（1992）.

4) J. Lewinson, W. Mayer, H. Wagner: Regul. Toxicol. Pharmacol., 20, 37 (1994).

5）藤正督，岩田宏敬，武井孝，渡辺徹，近沢正敏：粉体工 学, 32, 649 (1995). 
6）美谷芳雄，手嶋孝則，吉田康夫，山添昇：日本セラミッ ク協会誌，101，707（1993）。

7) M. Murota, H. Shirono : Proceedings of the 8th Annual Conference of the Korea Society for Image Science, p. 1 (1997).

8）善英喜：ジェティ，45, 113 (1997).

9）善英喜：ジェティ, 45, 75 (1997).

10）三家本純弘：ポリマーダイジェスト，35，92（1983).

11) K. Tsutsumi, H. Takahashi : Colloid Polym. Sci., 263, 506 (1985).
12）藤正督，荒木正和，武井孝，渡辺徹，近沢正敏：粉体工 学会誌, 36, 528 (1999).

13）江口隆之：プラスチック加工技術協会誌，6，1 (1979).

14）城野博州：色材，61，614（1988）.

15）須川忠昭，城野博州：資源処理技術，38，131（1991）.

16) E. Pluedemann: J. Adhes., 2, 184 (1970).

17) J. Mathias, G. Wannemacher: J. Colloid Interface Sci., 125, 61 (1988).

\title{
Effect of Alkyl Chain Length on the Reaction of Alkylalkoxysilane with Ultrafine Silica Particles in Dry System
}

\author{
Masamichi Murota* and Norio Tsubokawa** \\ * Graduate School of Science and Technology, Niigata University, 8050 \\ Ikarashi 2-nocho, Niigata, 950-2181, Japan \\ ${ }^{* *}$ Department of Material Science and Technology, Faculty of Engineering, \\ Niigata University, 8050 Ikarashi 2-nocho, Niigata, 950-2181, Japan
}

\begin{abstract}
The treatment of ultrafine silica surface with alkylalkoxysilane was carried out in a dry system for the introduction of alkyl groups onto the surface. In the treatment, water and alkylalkoxysilane were sprayed onto silica surface under nitrogen atmosphere and the reaction was conducted at $250^{\circ} \mathrm{C}$ for $180 \mathrm{~min}$ under agitation. The effects of the amount of alkylalkoxysilane and alkyl chain length of alkylalkoxysilane on the reaction of alkylalkoxysilane with silanol groups of the surface were investigated. The carbon content, hydrophobic nature, and charging of treated silica surface were found to increase and the content of surface silanol group decreased with increasing amount ratio of alkylalkoxysilane to silanol groups on the surface. The reactivity of alkylalkoxysilane with surface silanol groups decreased with increasing chain length of alkylalkoxysilane because of steric hindrance. In addition, the reactivity of alkylalkoxysilane with surface silanol groups increased with increasing number of methoxy groups of alkylalkoxysilane.
\end{abstract}

Key-words : Alkylalkoxysilane, Alkyl chain length, Ultrafine silica, Surface modification in dry system, Silanol group 